\title{
Real time polymerase chain reaction to diagnose Anaplasma marginale in cattle and deer (Ozotoceros bezoarticus leucogaster) of the Brazilian Pantanal
}

Reação da polimerase em cadeia tempo real para diagnóstico de Anaplasma marginale em bovino e veado campeiro do Pantanal brasileiro Ozotoceros bezoarticus leucogaster

Graziela Picoloto ${ }^{1 *}$; Renileide Ferreira de Lima²; Lílian Andressa Oliveira Olegárioº Cristiano Miranda Espínola Carvalho ${ }^{3}$; Ana Crystina Reis Lacerda ${ }^{4}$; Walfrido Moraes Tomás ${ }^{5}$; Paulo André Lima Borges ${ }^{5}$; Aiesca Oliveira Pellegrin ${ }^{5}$; Cláudio Roberto Madruga ${ }^{6}$

\author{
${ }^{1}$ Programa de Mestrado em Ciência Animal, Universidade Federal de Mato Grosso do Sul - UFMS, bolsista Fundect \\ ${ }^{2}$ Programa de Pós-Graduação em Biotecnologia, Universidade Federal de Lavras - UFLA \\ ${ }^{3}$ Programa de Mestrado em Biotecnologia, Universidade Católica Dom Bosco - UCDB \\ ${ }^{4}$ Programa de Pós-Graduação em Biologia Animal, Universidade de Brasília - UnB \\ ${ }^{5}$ Centro de Pesquisa Agropecuária do Pantanal - Embrapa Pantanal \\ ${ }^{6}$ Programa de Mestrado em Ciência Animal, Universidade Federal de Mato Grosso do Sul - UFMS
}

Received October 30, 2009

Accepted June 15, 2010

\begin{abstract}
Epizootiological study of Anaplasma marginale in regions that contain various reservoir hosts, co-existence of rickettsia pathogens, and common vectors is a complicated task. To achieve diagnosis of this rickettsia in cattle and campeiro deer of Brazilian Pantanal, a comparison was made between a real time polymerase chain reaction (RT-PCR) with intercalating Sybr Green fluorochrome and primers based on $m s p 5$ gene of $A$. marginale; a conventional PCR (C-PCR); and parasitological examination using thin blood smear stained with Giemsa-MayGrunwald. Both PCRs showed good performance in the diagnosis of $A$. marginale in cattle, and were superior to the parasitological exam. The RT-PCR detected seven positive campeiro deer (16.3\%). This rate was significantly higher compared to C-PCR, which identified one animal as positive (2.3\%), and also compared to parasitological diagnosis, which did not find any positive animals. The dissociation temperature average of positive reactions in cattle $\left(81.72{ }^{\circ} \mathrm{C} \pm 0.20\right)$ was identical to dissociation temperature found in the cervids $\left(81.72{ }^{\circ} \mathrm{C} \pm 0.12\right)$, suggesting that both animal species were infected with $A$. marginale. We concluded that RT-PCR can be used for $A$. marginale diagnosis and in epizootiological studies of cattle and cervids; in spite of the small number of campeiro deer samples, the results indicated that this wildlife species has importance in the Anaplasma epizootiology in the Brazilian Pantanal.
\end{abstract}

Keywords: Anaplasma marginale, real time PCR, cattle, campeiro deer, Pantanal.

\section{Resumo}

O estudo epizootiológico de Anaplasma marginale em regióes que existem vários reservatórios, co-existência de espécies de riquétsias patógenas e vetores comuns é uma tarefa complicada. Com o objetivo de obter o diagnóstico dessa riquétsia em bovinos e veado campeiro do Pantanal brasileiro foi avaliada uma reação da polimerase em cadeia em tempo real (PCR-TR) com o fluoróforo intercalante de fita dupla de DNA Sybr Green e iniciadores baseados na seqüência do gene $m s p 5$ de A. marginale comparando-a a uma PCR convencional (PCR-C) e ao exame parasitológico de esfregaço fino de sangue corado com Giemsa-MayGrunwald. Ambas PCRs apresentaram bom desempenho no diagnóstico de A. marginale nos bovinos, o qual foi superior ao exame parasitológico. O PCR-TR detectou sete veados campeiros positivos (16,3\%), o que foi significativamente maior comparado ao PCR-C identificando um animal como positivo (2,3\%), e ao exame parasitológico não encontrou nenhum animal positivo. A média da temperatura de dissociação das reaçóes positivas para amostras de bovinos $\left(81,72{ }^{\circ} \mathrm{C} \pm 0,20\right)$ foi idêntica àquelas dos cervídeos $\left(81,72{ }^{\circ} \mathrm{C} \pm 0,12\right)$, o que sugere que ambas espécies animais foram infectadas por $A$. marginale. Concluímos que PCR-TR pode ser utilizada para diagnóstico e estudos epizootiológicos de $A$. marginale em bovinos e cervídeos. Apesar da pequena amostragem de veado campeiro os resultados indicam que essa espécie de animal selvagem tem importância na epizootiologia do Anaplasma no Pantanal brasileiro.

Palavras-chave: Anaplasma marginale, PCR tempo real, bovino, veado campeiro, Pantanal.

\footnotetext{
*Corresponding author: Graziela Picoloto

Programa de Mestrado em Ciência Animal,

Universidade Federal de Mato Grosso do Sul - UFMS, bolsista Fundect,

Av. Felinto Muller, 2443, CP 549, CEP 79070-900, Bairro Ipiranga,

Campo Grande - MS, Brazil;

e-mail: graziela.picoloto@gmail.com
} 
The intraerythrocytic Anaplasma sp microorganisms of the Rickettsiales order and Anaplasmataceae family (DUMLER et al., 2001) cause in susceptible animals fever, anemia, icteric, anorexia, weight loss, and abortion (KOCAN et al., 2003). Anaplasma marginale produces considerable economic losses to the cattle industry of tropical and subtropical regions of the world due to significant productivity reduction and mortality (KOCAN et al., 2003). In regions where wild ruminant populations are abundant, particularly cervids, which have been implicated as important reservoirs and infection sources of $A$. marginale (DE LA FUENTE et al., 2008), epizootiological studies of this rickettsia are more complicated due to various reservoir hosts, co-existence of rickettsia pathogens, and common vectors. As well as being infected by $A$. marginale, the cervids are also infected with Anaplasma phagocitophylum (DUMLER et al., 2001) and Anaplasma ovis (HAIGH et al., 2008), which makes it difficult to implement a surveillance by serology. The current serological tests display crossed reactions, even when antigenic sub-units such as MSP5 recombinant protein are employed as antigens, because Anaplasma species have similar B epitopes (STRIK et al., 2007).

Several molecular diagnostic methods with high levels of sensitivity and specificity are used, such as reverse line blotting (GUBBELS et al., 1999), conventional polymerase chain reaction (C-PCR) (FRENCH et al., 1998), semi-nested, nested PCR (MOLAD et al., 2006) and real time PCR (RT-PCR) (DECARO et al., 2008). This last technique presents some advantages, such as speed of obtaining results, quantification of the infection level, and a minor probability of contamination. So far, the RT-PCR that has been developed to detect anaplasma in bovines uses the Taqman system as a reaction indicator (DECARO et al., 2008). This system requires a specific probe with a fluorescent reagent and a fluorescence emission quencher, making it more expensive than the technique that utilizes double strand DNA intercalating fluophore, the Syber Green. Because previously RT-PCR with primers based on genes $m s p 5$ and $m s p 2$ and Syber Green were used only to detect $A$. marginale gene transcription in the tick vector (FUTSE et al., 2003), this work evaluated a RT-PCR using primers with sequences of the $m s p 5$ gene with Sybr Green for diagnostic and epizootiological study of $A$. marginale in bovines and cervids.

To assess RT-PCR in the diagnosis of $A$. marginale in bovines, three experimental groups were established according to the following descriptions. Group 1 consisted of ten Brangus calves raised in the isolation area at the Embrapa Gado de Corte, Campo Grande, Mato Grosso do Sul State, seven to nine months of age, serologically negative in enzyme linked immunosorbent assay with recombinant proteins of $A$. marginale, MSP2 (ARAÚJO et al., 2005), and MSP5 (SILVA et al., 2006) and in conventional PCR (C-PCR) (ARAÚJO et al., 2005). Group 2 consisted of ten Brangus calves raised in an endemic area for $A$. marginale, ratified as positive by the above diagnostic tests. Group 3 consisted of eight Brangus calves of the same age and raised in the same isolation area, confirmed as negative through the above diagnostic tests and immunized with attenuated Babesia bovis and B. bigemina to avoid babesiosis sintomatology. These calves subsequently were exposed to $A$. marginale infection by ticks (20 engorged female Rhipichephalus (B.) microplus that grew on $A$. marginale bovine carriers) or mechanical transmission by insects. To evaluate RT-PCR in the diagnosis of $A$. marginale in campeiro deer (Ozotoceros bezoarticus leucogaster) of the Pantanal of the Mato Grosso do Sul State, fourty three campeiro deer were captured (IBAMA authorization number: (005/2007) 02014.000382/2007-22). The capture was done using anesthetic darts according to PIOVEZAN et al. (2006). The $A$. marginale direct diagnosis was performed by thin blood smears from capillaries of calves' ears and stained with May-Grunwald Giemsa, C-PCR according to ARAÚJO et al. (2005), and by RT-PCR. For the RT-PCR procedure, the reaction was obtained in a $25 \mu \mathrm{L}$ volume containing PlatinunSYBR Green qPCR SuperMix-UDG (Invitrogen), primers forward 5'-AAGGCGAGGAGCTGTTTAAG-3' and reverse 5'-CTACTGCCTCACAAGGACGA-3' based on the sequence of the gene $m s p 5$ of $A$. marginale, at concentration of $20 \eta \mathrm{g} . \mu \mathrm{L}^{-1}$, and DNA at concentration of $5 \eta \mathrm{g} \cdot \mu^{-1}$. Three stages were programmed in the thermocycler (Cepheid Smart Cycler): 1) one cycle at $95^{\circ} \mathrm{C}$ for 600 seconds; 2) 35 cycles at $95^{\circ} \mathrm{C}$ for 15 seconds and $52^{\circ} \mathrm{C}$ for 45 seconds; and 3) 60 cycles at $95^{\circ} \mathrm{C}$, for two hundredths of a second, to create the dissociation curve or melting curve. The statistical analysis was done by McNemar test.

The RT-PCR standardization with DNA samples obtained from blood of $A$. marginale infected cattle, showed positive reactions, while blood samples from animals free of this rickettsia infection did not show amplicons. The same results were verified in the C-PCR. In the calves of group 3, RT-PCR and C-PCR showed similar results, with the first $A$. marginale detection by both PCRs at Day 21 after exposure of the calves to tick or insect transmission, while in the peripheral blood smears $A$. marginale was observed at the $26^{\text {th }}$ day post challenge. The only disagreement between the PCRs occurred with the sample from calf number 6 , at 59 days post challenge, which displayed positive reaction only in the C-PCR.

The campeiro deer thin blood smear examination did not detect A. marginale. Using C-PCR one animal was detected as positive (2.3\%), while RT-PCR found seven positive reactions (16.3\%), which resulted in a significant statistical difference between the molecular diagnostics. Therefore, RT-PCR using Sybr Green demonstrated superior performance as a diagnostic tool.

The RT-PCR described here has advantages over the recently developed RT-PCRs (DECARO et al., 2008), since they employ a Taqman system, which increases the tests costs, compared to method that uses the intercalating fluorochrome of DNA double strand. Another advantage is the use of the dissociation temperature, which confers a diagnostic specificity that is important for epizootiological studies.

There is serological evidence that cattle infection with A. phagocitophylum occurs in areas endemic for $A$. marginale (DE LA FUENTE et al., 2008), as well as deer with infections of A. phagocitophylum and A. ovis (DUGAN et al., 2006). However, crossed reactions in serological tests (even when using recombinant protein MSP5; STRIK et al., 2007), due to common antigens between the species of Anaplasma (DREHER et al., 2005), do not allow a conclusive diagnosis of Anaplasma species infecting cattle and cervids. Also, the gene msp5 is considered highly conserved between Anaplasma species (KNOWLES et al., 1996), consequently there is possibility of amplicon production in the PCR with primers based on this gene sequence for different Anaplasma species.

However, msp 5 gene blast of different Anaplasma species displays different degrees of identity in the gene sequence; for instance 


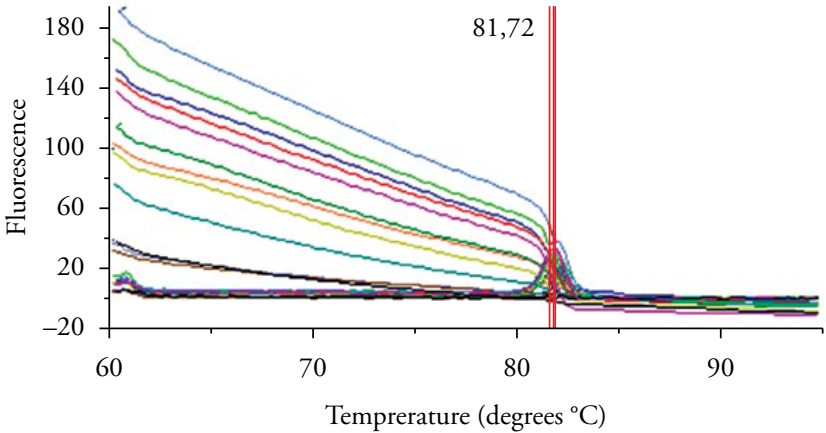

Figure 1. Melting temperature in the Real Time PCR (RT-PCR) performed with DNA extracted from calves infected with Anaplasma marginale.

A. marginale $m s p 5$ has 89,85 , and $65 \%$ of identity, respectively, with ortologous genes of $A$. ovis, A. centrale, and A. phagocitophylum. It is likely that the RT-PCR melting curve would show distinct temperature dissociation for each Anaplasma species. Since the average temperature of dissociation in positive reactions in cattle $(81.72 \pm 0.20)$ (Figure 1) and in campeiro deer $(81.72 \pm 0.12)$ were identical, there is the suggestion that both animal species were infected with $A$. marginale. This finding agrees with the fact that only $A$. marginale was found infecting deer in Brazil by a direct diagnosis with PCR (MACHADO et al., 2006).

In conclusion, this RT-PCR showed good performance as a diagnostic test for $A$. marginale in cattle and in campeiro deer, as suggested by dissociation temperature. Despite the small number of campeiro cervid samples, the results pointed to the importance of these animals as Anaplasma reservoirs in the Brazilian Pantanal. A complementary study on dissociation temperature of $A$. ovis, A. centrale, and $A$. phagocitophylum in this RT-PCR would be relevant for its use in epizootilogical studies of Anaplasma sp., in regions or farms where various animals species co-exist.

\section{References}

ARAÚJO, F. R. et al. Development of enzime-linked immunosorbent assays based on recombinant MSP1a and MSP2 of Anaplasma maginale. Memórias do Instituto Oswaldo Cruz, v. 100, n. 7, p. 765-769, 2005.

DE LA FUENTE, J. et al. Evidence of Anaplasma infections in European roe deer (Capreolus capreolus) from southern Spain. Research in Veterinary Science, v. 84, n. 3, p. 382-386, 2008.

DECARO, N. et al. Duplex real-time polymerase chain reaction for simultaneous detection and quantification of Anaplasma marginale and Anaplasma centrale. Journal of Veterinary Diagnostic Investigation, v. 20, n. 5, p. 606-611, 2008.
DREHER, U. M.et al. Serologic cross-reactivity between Anaplasma marginale and Anaplasma phagocytophilum. Clinical and Diagnostic Laboratory Immunology, v. 12, n. 10, p. 1177-1183, 2005.

DUGAN, V. G. et al. Evaluation of white-tailed deer (Odocoileus virginianus) as natural sentinels for Anaplasma phagocytophilum. Vector- Borne and Zoonotic Diseases, v. 6, n. 2, p. 192-207, 2006.

DUMLER, J. S. et al. Reorganization of genera in the families Rickettsiaceae and Anaplasmataceae in the order Rickettsiales: unification of some species of Ehrlichia with Anaplasma, Cowdria with Ehrlichia and Ehrlichia with Neorickettsia, descriptions of six new species combinations and designation of Ehrlichia equi and 'HGE agent' as subjective synonyms of Ehrlichia phagocytophila. International Journal of Systematic and Evolutionary Microbiology, v. 51, n. 6, p. 2145-2165, 2001.

FRENCH, D. M. et al. Expression of Anaplasma marginale major surface protein 2 variants during persistent cyclic rickettsemia. Infection and Immunity, v. 66, n. 3, p. 1200-1207, 1998.

FUTSE, J. E. et al. Transmission of Anaplasma marginale by Boophilus microplus: retention of vector competence in the absence of vector-pathogen interaction. Journal of Clinical Microbiology, v. 41, n.8, p. 3829-3834, 2003.

GUBBELS, J. M. et al. Simultaneous detection of bovine Theileria and Babesia species by reverse line blot hybridization. Journal of Clinical. Microbiology, v. 37, n. 6, p. 1782-1789, 1999.

HAIGH, J. C. et al. A novel clinical syndrome and detection of Anaplasma ovis in Mongolian reindeer (Rangifer tarandus). Journal of Wildlife Diseases, v. 44, n. 3, p. 569-577, 2008.

KNOWLES, D. et al. Antibody against an Anaplasma marginale MSP5 epitope common to tick and erythrocyte stages identifies persistently infected cattle. Journal of Clinical Microbiology, v. 34, n. 9, p. 2225-2230, 1996.

KOCAN, K. M. et al. Antigens and alternatives for control of Anaplasma marginale infection in cattle. Clinical Microbiology Reviews, v. 16, n. 4, p. $698-712,2003$.

MACHADO, R. Z. et al. Detection of Ehrlichia chaffeensis in Brazilian marsh deer (Blastocerus dichotomus). Veterinary Parasitology, v. 139, n. 1-3, p. $262-266,2006$.

MOLAD, T. et al. Molecular and serological detection of $A$. centrale- and A.marginale-infected cattle grazing within an endemic area. Veterinary Microbiology, v. 113, n. 1-2, p. 55-62, 2006.

PIOVEZAN, U.; ZUCCO, C. A.; ROCHA, F. L. Uso de dardos anestésicos para a captura de veados campeiros (Ozotoceros bezoarticus) no Pantanal. Embrapa Pantanal, 2006. 22 p. Boletim de Pesquisa e Desenvolvimento.

SILVA, V. M. G. et al. Comparison between indirect enzime-linked immunosorbent assays for Anaplasma marginale antibodies with recombinant major surface protein 5 and initial body antigens. Memórias do Instituto Oswaldo Cruz, v. 101, n. 5, p. 511-516, 2006.

STRIK, N. I. et al. Characterization of Anaplasma phagocytophilum Major Surface Protein 5 and the Extent of Its Cross-Reactivity with A. marginale. Clinical and Vaccine Immunology, v. 14, n. 3, p. 262-268, 2007. 